\title{
Impact of Physical Processes on Chlorophyll Distribution in the Bay of Bengal
}

\author{
P. N. Vinayachandran \\ Centre for Atmospheric and Oceanic Sciences, Indian Institute of Science, Bangalore, India
}

Satellite-derived chlorophyll $a$ concentration ( $\operatorname{chl} a$ ) maps show three regions with high chl $a$ in the Bay of Bengal. First among these is close to the coast, particularly off river mouths, with high values coinciding with the season of peak discharge; second is in the southwestern bay during the northeast monsoon, which is forced by local Ekman pumping; and the third is to the east of Sri Lanka in response to the summer monsoon winds. Chlorophyll-rich water from the mouths of rivers flows either along the coast or in an offshore direction, up to several hundred kilometers, depending on the prevailing ocean current pattern. The Irrawady River plume flows toward offshore and then turns northwestward during October-December, but it flows along the coast into the Andaman Sea for the rest of the year. From the Ganga-Brahmaputra river mouth, chl $a$-rich water flows directly southward into the open bay during spring but along the Indian coast during summer and winter. Along the Indian coast, the flow of chl $a$-rich water is determined by the East India Coastal Current (EICC). Whenever the EICC meanders off the Indian coast, it leads to an offshore outbreak of chl $a$-rich water from the coastal region into open ocean. The EICC as well as open ocean circulation in the bay is made up of several eddies, and these eddies show relatively higher chl $a$. Eddies near the coast, however, can often have higher chl $a$ because of advection from the coastal region rather than generation within the eddy itself. The bay experiences several cyclones in a year, most of them occurring during October-November. These cyclones cause a drop in the sea surface temperature, a dip in the sea level, and a local increase in chl $a$. The impact of a cyclone is weaker in the northern part of the bay because of stronger stratification compared to the southern parts.

\section{INTRODUCTION}

The Bay of Bengal (hereinafter referred to as the bay) is a semienclosed tropical ocean basin that forms the northeastern part of the Indian Ocean (Figure 1). The bay opens into

Indian Ocean Biogeochemical Processes and Ecological Variability Geophysical Monograph Series 185

Copyright 2009 by the American Geophysical Union. 10.1029/2008GM000705 the equatorial Indian Ocean at the south and is bordered by Sri Lanka, India, Bangladesh, and Myanmar. The Andaman and Nicobar Islands separate the bay from the Andaman Sea, and connection between the two basins is possible through the channels between islands. The bay has a unique setting from a physical oceanographic viewpoint. It comes under the influence of monsoon climate regime, where winds reverse twice during the year. Winds over the bay blow from the southwest during May-September and from the northeast during November-January. In addition, there is a large influx of fresh water into the bay in the form of both rainfall 


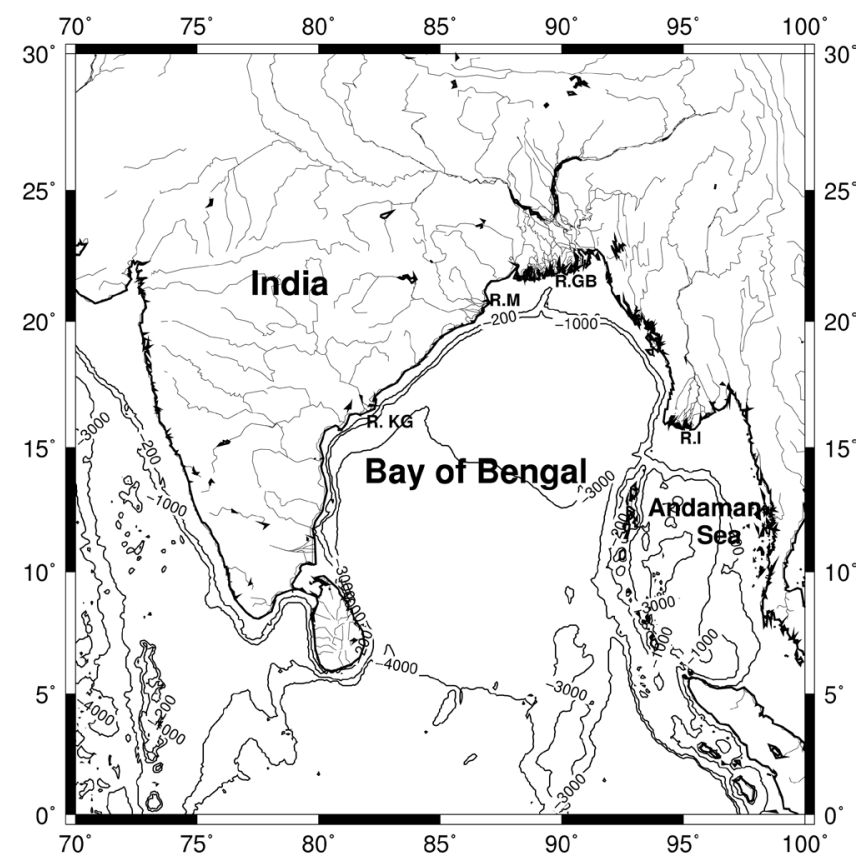

Figure 1. A map of the Bay of Bengal. Bathymetric contours of 200, 1000, 3000, and $4000 \mathrm{~m}$ are shown. Thin lines on the land indicate rivers. R.KG, R.M, R.GB, and R.I show locations of mouths of rivers Krishna-Godavari, Mahanadi, Ganges-Brahmaputra, and Irrawady, respectively.

and river discharge. The bay receives about $1.5 \times 10^{12} \mathrm{~m}^{3}$ of fresh water as river runoff [Martin et al., 1981], which is much larger compared to the flow of fresh water into the Arabian Sea. This large freshwater influx distinguishes the bay: there is no other ocean basin that is subjected to seasonally reversing winds and that receives such a large freshwater influx. A third forcing of the bay arises out of its proximity to the equatorial Indian Ocean. The coastal waveguide of the bay connects to the equatorial waveguide through the eastern boundary of the bay and allows penetration of wind forcing in the equatorial Indian Ocean all along the coast [Potemra et al., 1991; Yu et al., 1991; McCreary et al., 1993, 1996b, 2001; Vinayachandran et al., 1996; Shankar et al., 2002]. The combination of monsoon winds, freshwater input, and remote forcing from the equator, which is unique anywhere in the world oceans, forces the seasonal circulation in the bay. Possible impact of physical processes on the biological activity is addressed in this study using satellite-derived chlorophyll $a$ concentration ( $\mathrm{chl} a)\left(\mathrm{mg} \mathrm{m}^{-3}\right)$ data sets. Understanding this link is crucial for unraveling reasons behind the contrasting biogeophysical characteristics of the Arabian Sea and the bay and for assessing and quantifying impacts associated with climate change on the ecosystem [Hood et al., 2008].

The bay has been known to be a region of low biological productivity compared to the Arabian Sea [Qasim, 1977; Radhakrishna et al., 1978]. This point has been reiterated by nearly all shipboard observations in the bay [Pant, 1992; Gomes et al., 2000; Madhupratap et al., 2003; Prasanna Kumar et al., 2002; Jyothibabu et al., 2004; Gauns et al., 2005]. A major reason for this low productivity is the influence of fresh water. The fresh water that caps the upper layer of the bay leads to the formation of a strong halocline below the mixed layer [Vinayachandran et al., 2002]. Even the strong southwest monsoon (SWM) winds are unable to break this strong stratification [Shenoi et al., 2002] so as to permit transfer of nutrients from the nutricline to the euphotic zone. Cloud cover during the SWM, suspended sediments in the water column, and the narrow continental shelf have also been implicated by these investigators as probable reasons for lower productivity.

Several physical processes, nevertheless, promote biological activity in the bay by bringing nutrients into the euphotic zone from subsurface depths and thereby leading to phytoplankton blooms. There is upwelling along the southern part of the Indian coast during the summer monsoon, driven by local alongshore winds [Shetye et al., 1991], which enhances biological productivity in this region [Gomes et al., 2000; Madhupratap et al., 2003; Muraleedharan et al., 2007; Madhu et al., 2006]. Coastal upwelling also leads to an increase in chl $a$ along the southern coast of Sri Lanka [Vinayachandran et al., 2004]. The open ocean Ekman pumping driven by positive cyclonic wind stress curl enhances chl $a$ in the southwestern part of the bay during the northeast monsoon (NEM) [Vinayachandran and Mathew, 2003; Vinayachandran et al., 2005b] and within the Sri Lanka dome [Vinayachandran and Yamagata, 1998] during the SWM [Vinayachandran et al., 2004]. Cyclonic eddies are associated with upwelling of nutrients and high biological productivity [Falkowski et al., 1991; McGillicuddy et al., 2003], and this process has been found to trigger biological productivity in the bay [Gomes et al., 2000; Prasanna Kumar et al., 2002, 2007; Muraleedharan et al., 2007]. Tropical cyclones blowing over the bay are also capable of breaking the strong stratification, thereby injecting nutrients into the euphotic zone, leading to phytoplankton blooms [Nayak et al., 2001; Madhu et al., 2002; Vinayachandran and Mathew, 2003; Rao et al., 2006; Patra et al., 2007]. Along the coastal region of the bay, rivers act as a major source of nutrients, enhancing productivity. Each of these processes are addressed in this study with respect to the spatiotemporal occurrence of chl $a$ distribution. The main objective is to identify regions that have high chl $a$ and to examine the processes 


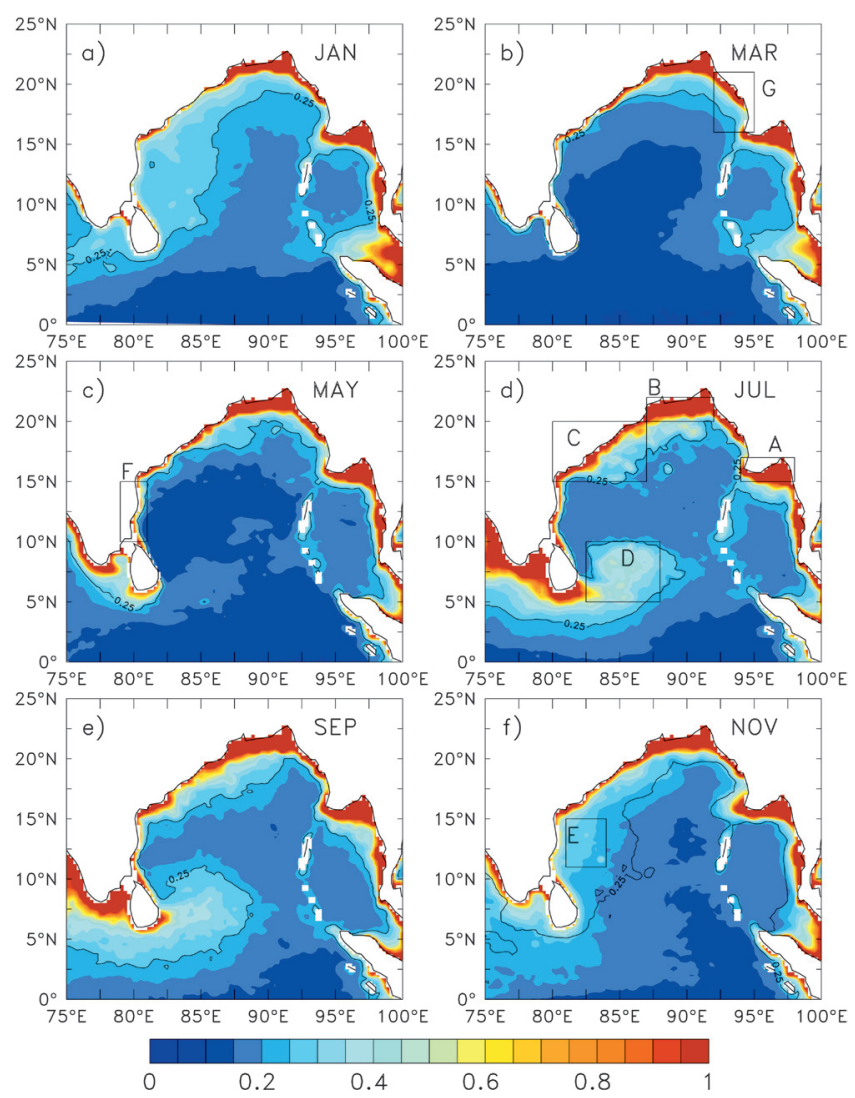

Plate 1. Bimonthly maps of chl $a\left(\mathrm{mg} \mathrm{m}^{-3}\right)$ distribution obtained from SeaWiFS: (a) January, (b) March, (c) May, (d) July, (e) September, and (f) November. The climatology is for the period November 1999 to October 2006. Values higher than $1 \mathrm{mg} \mathrm{m}^{-3}$ (which in this map occur only close to the coast) are truncated, and $0.25 \mathrm{mg} \mathrm{m}^{-3}$ is shown by a contour. Boxes A-G marked in Plates 1d, 1f, 1c, and 1b refer to Figures 2, 3, and 6.

that lead to the observed chl $a$ pattern using relevant physical oceanographic parameters.

\section{CHLOROPHYLL DISTRIBUTION}

Satellite-derived chl $a$ maps have become available for the bay since the launch of the Ocean Color and Temperature Scanner (OCTS) on board ADEOS in 1996 (the Coastal Zone Color Scanner did not have sufficient coverage over the bay). The sensors that followed, namely, the Sea-viewing Wide Field-of-View Sensor (SeaWiFS), the Ocean Colour Monitor (OCM), and the Moderate Resolution Imaging Spectroradiometer (MODIS) have added to this data resource. This study exploits the SeaWiFS data set that is available from 1997 onward to study the seasonal cycle of chl $a$ distribution in the bay. Lévy et al. [2007] have demonstrated the usefulness of the SeaWiFS data set to describe the climatology of phytoplankton blooms in the Indian Ocean.
In this study, 8-day composite maps of chl $a$ measured by SeaWiFS, provided by NASA Goddard Space Flight Center, United States, for the period September 1997 to December 2006 at a spatial resolution of $9 \mathrm{~km}$ are used.

Validation of satellite-derived chl $a$ data requires colocated in situ measurements. In the absence of such a data set, comparison with available nonsimultaneous measurements can give an idea about the relative accuracy of the satellite measurements vis-à-vis in situ measurements. A comparison of this kind suggests that chl $a$ data obtained from SeaWiFS are not too different from shipboard observations. Madhu et al. [2002] carried out spectrophotometric estimation of chl $a$ using water samples collected at nine locations in the southwestern bay during July-August 1999. They reported surface chl $a$ values in the range of 0.14 to $0.46 \mathrm{mg} \mathrm{m}^{-3}$. The corresponding range obtained from the SeaWiFS data set is 0.14 to $0.63 \mathrm{mg} \mathrm{m}^{-3}$. During November 1999, their shipboard measurements ranged from 0.22 to $0.97 \mathrm{mg} \mathrm{m}^{-3}$, 

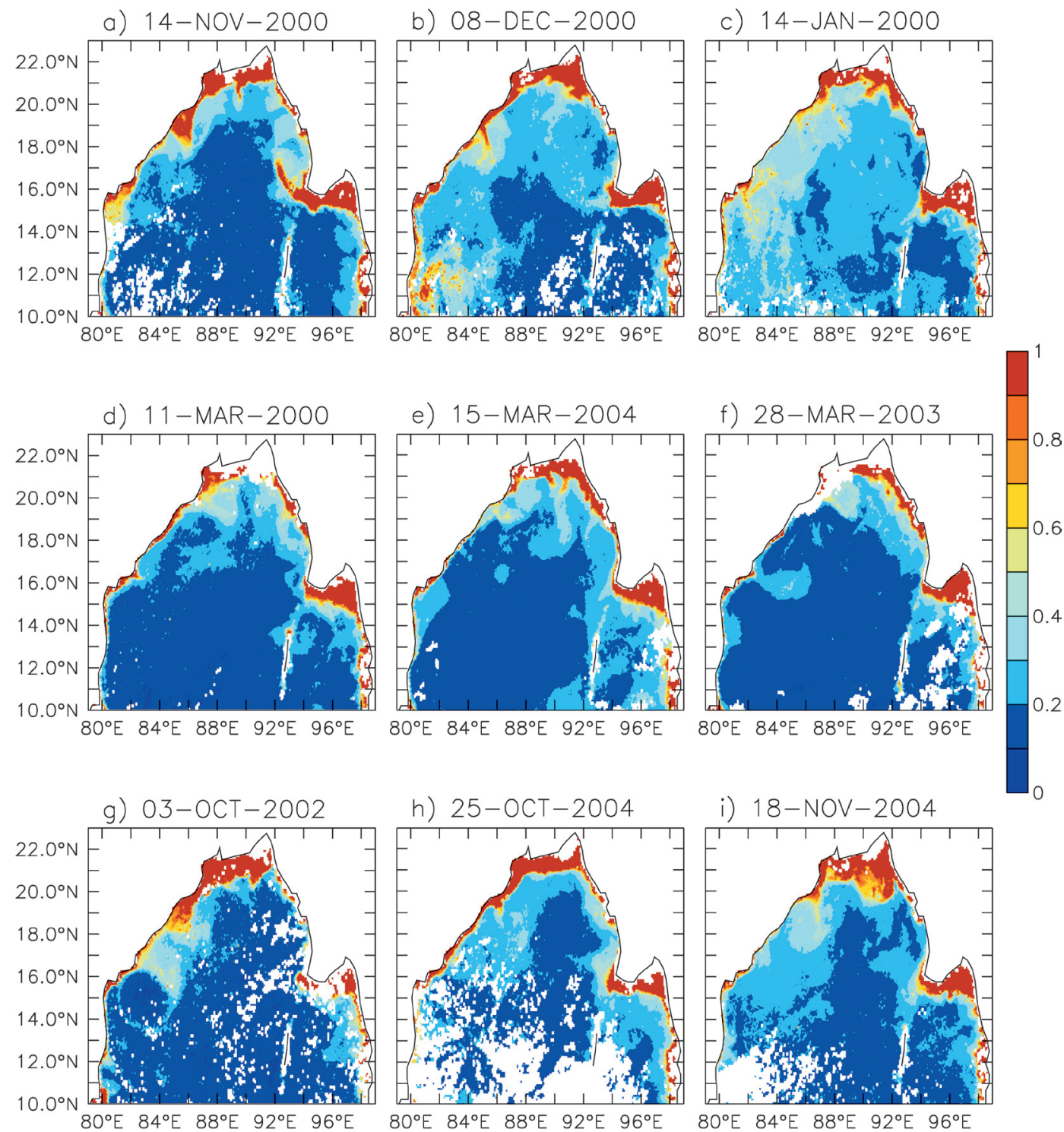

Plate 2. SeaWiFS chl $a\left(\mathrm{mg} \mathrm{m}^{-3}\right)$ for selected days (shown above each plot). Values above $1 \mathrm{mg} \mathrm{m}^{-3}$ are truncated.

and SeaWiFS data showed a range of 0.16 to $1.2 \mathrm{mg} \mathrm{m}^{-3}$. Muraleedharan et al. [2007] found surface chl $a$ in the range of 0.12 to $0.25 \mathrm{mg} \mathrm{m}^{-3}$ in the western bay during the SWM of 2003. Available SeaWiFS measurements are in the same range except that grid points closest to the coast show much higher values. During the 2001 SWM, the surface chl $a$ along $88^{\circ} \mathrm{E}$ was found to vary from $0.06 \mathrm{mg} \mathrm{m}^{-3}$ in the south to $0.28 \mathrm{mg} \mathrm{m}^{-3}$ in the north [Madhupratap et al., 2003; Prasanna Kumar et al., 2002]. SeaWiFS data show a value of $0.07 \mathrm{mg} \mathrm{m}^{-3}$ at $12.5^{\circ} \mathrm{N}$, which increased to $0.15 \mathrm{mg}$ $\mathrm{m}^{-3}$ at $11^{\circ} \mathrm{N}$ and $0.25 \mathrm{mg} \mathrm{m}^{-3}$ at $18^{\circ} \mathrm{N}$.
On the basis of monthly maps of chl $a$ distribution (Plate 1 ), the regions in the bay that show high biological activity can be classified into three: First among these is located, throughout the year, near the coast and off the mouths of rivers; the second is to the east of Sri Lanka during SWM; and the third is in the southwestern bay during the NEM. Boxes $\mathrm{A}, \mathrm{B}$, and $\mathrm{C}$ shown in Plate $1 \mathrm{~d}$ represent the coastal region off river mouths, and box D represents the region to the east of Sri Lanka. Box F shown in Plate 1c is chosen to represent the southwestern bay. A monthly climatology of chl $a$ was first constructed for the period November 1999 to October 
2006, and then the annual cycle of chl $a$ averaged over each of these regions was plotted (Figures 2 and 3).

\subsection{River Mouths and Coastal Region}

The highest chl $a$ anywhere in the bay is seen off the mouths of the Irrawady River (Figure 2, dashed curve). In this region (box A shown in Plate 1d), the peak in the annual cycle occurs during the NEM with chl $a$ reaching nearly 6 $\mathrm{mg} \mathrm{m}{ }^{-3}$. In contrast to the rest of coastal region, minimum chl $a$ is seen here during the SWM. Off the mouths of the Ganges-Brahmaputra River (box B shown in Plate 1d), high chl $a\left(>2 \mathrm{mg} \mathrm{m}^{-3}\right.$ ) is seen almost throughout the year (Figure 2, solid curve). During the SWM, this region of high chl $a$ stretches along the northwestern coast of the bay (Plate 1d) as the freshwater plume moves equatorward [Shetye et al., 1991; Vinayachandran and Kurian, 2007]. Near the river mouth, highest chl $a$ is seen during the month of August (Figure 2, solid curve) corresponding to the peak river discharge during this time. The Ganges-Brahmaputra river mouth has higher chl $a$ than that of other rivers along the western boundary (Figure 2, dot-dashed curve) such as Mahanadi and Krishna-Godavari, which is most probably related to the larger discharge volume of Ganga-Brahmaputra, which fertilizes a larger oceanic area.

\subsection{East of Sri Lanka}

The ocean around Sri Lanka is nearly oligotrophic during the month of March but a dramatic increase in chl $a$ takes place with the onset of the SWM. Here chl $a$ patches higher than $1 \mathrm{mg} \mathrm{m}^{-3}$ appear along the southern coast of Sri Lanka during April; by May there is high chl $a$ around the tip of India and the southern coast of Sri Lanka (Plate 1c), and the phytoplankton bloom develops fully by July (Plate 1d). The southern coast of Sri Lanka shows high values of chl $a$, and lower concentrations are seen along the west coast, whereas the eastern coast of Sri Lanka is almost devoid of chl $a$. High chl $a$, that extends up to $88^{\circ} \mathrm{E}$ and about $10^{\circ} \mathrm{N}$, is also observed to the east of Sri Lanka during the peak of the SWM (Figure 3, dashed curve) [Vinayachandran et $a l ., 2004]$. This eastward extension of the high-chl $a$ region into the southern bay occurs along the path of the Southwest Monsoon Current [Vinayachandran et al., 1999].

\subsection{Southwestern Bay of Bengal}

In this region (see box $\mathrm{F}$ in Plate 1f), chl $a$ increases during the first half of the SWM, followed by a short decrease during September, and then it increases rapidly to a peak value of about $0.35 \mathrm{mg} \mathrm{m}^{-3}$ in December (Figure 3, solid curve).
The chl $a$ during the NEM is nearly double that found during the SWM, and the lowest chl $a$ in the southwestern bay is found during the premonsoon months of February-April.

\section{PHYSICAL PROCESSES}

Phytoplankton grow in abundance in the presence of sunlight, utilizing nutrients dissolved in seawater, and consequently, a shortage of either light or nutrients limits their growth. In tropical oceanic regions, in general, light is not a limiting factor. However, the sky over the bay can remain cloudy for long periods during the SWM. Lack of a sufficient amount of light has been cited as one of the reasons for low biological productivity in the bay during the SWM [McGill, 1973; Gomes et al., 2000]. A more critical limiting factor in the tropics is the availability of nutrients. Supply of nutrients to the euphotic layer by upwelling (coastal or open ocean) and entrainment enhances chl $a$. Enhancement of phytoplankton, due to such processes, in response to strong monsoon winds is well known in the Arabian Sea [McCreary et al., 1996a; Lévy et al., 2007]. Even though the bay is also influenced by monsoons, the bay's response to monsoon is different from that of the Arabian Sea. It is believed that mixing and entrainment of cooler thermocline water with the warmer upper layer is nearly absent in the

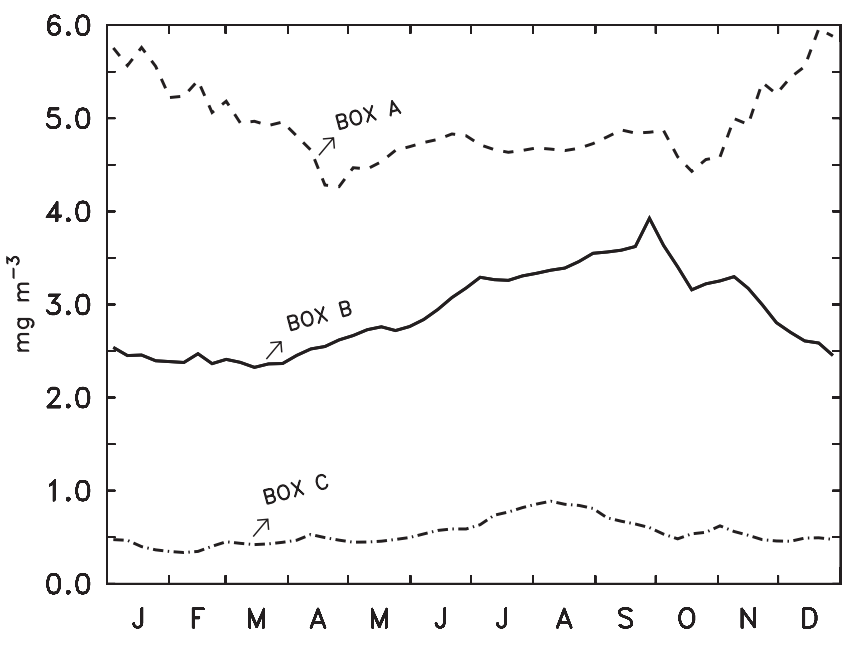

Figure 2. Annual cycle of chl $a\left(\mathrm{mg} \mathrm{m}^{-3}\right)$ near the mouths of Irrawady (dashed curve), Ganges-Brahmaputra (solid curve), and Mahanadi-Godavari-Krishna rivers (dot-dashed curve). For Irrawady, Ganga-Brahmaputra, and Mahanadi-Godavari-Krishna rivers, chl $a$ averaged over the oceanic region within the boxes bounded by $94^{\circ}-98^{\circ} \mathrm{E}, 15^{\circ}-17^{\circ} \mathrm{N}$ (box A shown in Plate $1 \mathrm{~d}$ ); $87^{\circ}-92^{\circ} \mathrm{E}, 20^{\circ}-$ $22^{\circ} \mathrm{N}$ (box B shown in Plate $1 \mathrm{~d}$ ), and $80^{\circ}-87^{\circ} \mathrm{E}, 15^{\circ}-20^{\circ} \mathrm{N}$ (box C in Plate 1d), respectively, is shown. 


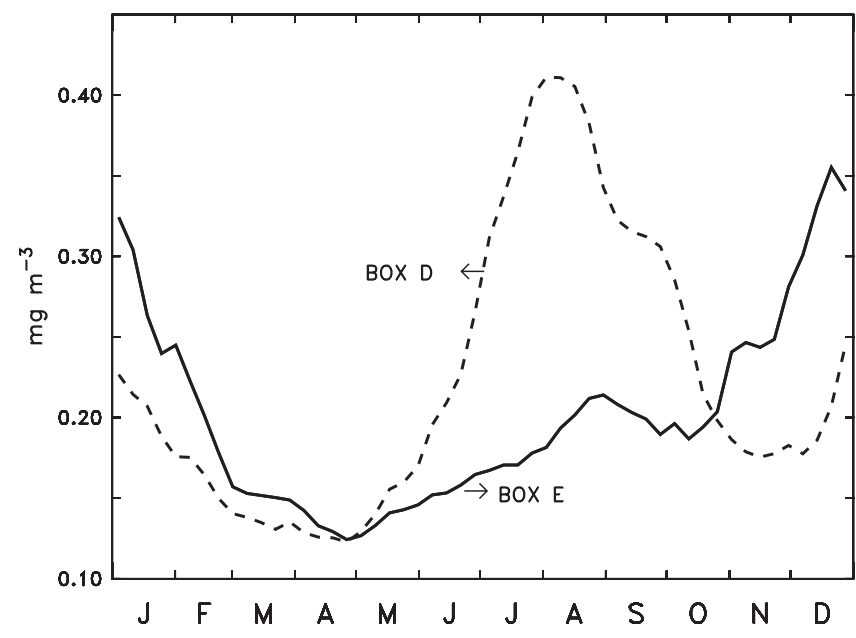

Figure 3. Annual cycle of chl $a\left(\mathrm{mg} \mathrm{m}^{-3}\right)$ to the east of Sri Lanka (dashed curve) and in the southwestern Bay of Bengal (solid curve). For east of Sri Lanka, chl $a$ averaged over the oceanic region within the box bounded by $82^{\circ}-88^{\circ} \mathrm{E}, 5^{\circ}-10^{\circ} \mathrm{N}$ (box D shown in Plate 1d) and for the southwestern bay the box bounded by $81^{\circ}-85^{\circ} \mathrm{E}$, $11^{\circ}-15^{\circ} \mathrm{N}$ (box E, Plate 1f) is chosen.

bay. This is attributed to the following: (1) The winds over the bay are much weaker than those over the Arabian Sea, and (2) stratification in the bay is strong and demands higher energy for mixing [Shenoi et al., 2002]. This is clearly seen in the maps of Monin-Obukov length, which is a measure of the depth up to which mixing can take place for a given wind, buoyancy forcing and stratification [Rao et al., 2002]. Nevertheless, section 2 illustrates that there are regions and times when this barrier breaks, allowing blooming of phytoplankton. In sections 3.1-3.4, we examine the processes responsible for such blooms.

\subsection{Winds}

March and April are the transition periods or spring intermonsoon months for the bay (Figure 4). During this period, winds are weak, but they have a well-defined anticyclonic curl with its center located in the central bay. The southwesterlies set in and envelope the entire bay during May, and these winds persist until the end of September. The transition from southwesterlies to northeasterlies takes place during October when there is a cyclonic curl in the western bay and southwesterlies in the south. Strong northeasterlies occur during the November-February period, but they are weak in the northern bay during February.

The annual cycle of wind speed over the bay shows a plateau during the summer monsoon, which drops drastically toward either side (Figure 5). The climatological wind speed is at its minimum of about $2 \mathrm{~m} \mathrm{~s}^{-1}$ during March-April and October; it is higher at about $8 \mathrm{~m} \mathrm{~s}^{-1}$ during July-August. During November-February, the southern bay experiences stronger (by $2 \mathrm{~m} \mathrm{~s}^{-1}$ ) winds than the northern bay, but during the spring transition (March-May) winds are stronger (by 2 $\mathrm{m} \mathrm{s}^{-1}$ ) over the northern bay.

3.1.1. Coastal upwelling. The SWM winds blow toward the west coast of Sri Lanka and away from its east coast with the alongshore component being nearly close to zero. However, they blow almost parallel to its southern coast making it favorable for upwelling. Consequently, coastal upwelling leads to high biological production along the southern coast of Sri Lanka [Vinayachandran et al., 2004]. Winds along the eastern Indian coast are favorable for upwelling during the SWM. Weak upwelling has been observed along the southern part of the coast in hydrographic surveys [Shetye et al., 1991]. A rapid increase in chl $a$ in this region is seen in response to the SWM (Figure 6, dashed curve). Even though the winds have a strong alongshore component to the north of $15^{\circ} \mathrm{N}$, upwelling is not prevalent in this region because of the equatorward advection of a river plume [Shetye et al., 1991; Vinayachandran and Kurian, 2007] and the propagation of a downwelling coastal Kelvin wave [McCreary et al., 1996b; Vinayachandran et al., 1996]. However, considering that there is a time lag between the influence of river discharge versus local upwelling, it appears that an increase in chl $a$ during the early part of the summer monsoon (Figure 2, dot-dashed curve) could be due to coastal upwelling. Along the northeastern coast of the bay, winds are favorable for coastal upwelling during December-March (Figure 4) [McCreary et al., 1996b]. Here chl a distribution shows a distinct increase during January, and peak chl $a$ in the annual cycle occurs during February (Figure 6, solid curve), which is most probably driven by local coastal upwelling.

3.1.2. Ekman pumping. Ekman pumping driven by the curl of local wind stress is an important forcing function of the bay. Downward Ekman pumping during February-April is a major driving mechanism of the anticyclonic gyre during that season [Shetye et al., 1993; Shankar et al., 1996; McCreary et al., 1996b]. Upward Ekman pumping east of Sri Lanka during the SWM leads to the formation of the Sri Lanka dome and a cyclonic gyre in the southwestern bay during the NEM [Vinayachandran and Yamagata, 1998]. Open ocean bloom seen in the southwestern Bay of Bengal during the NEM is caused by Ekman pumping [Vinayachandran and Mathew, 2003]. The bay is least productive during the premonsoon months of February-April when Ekman pumping is directed downward, whereas regions of upward Ekman pumping (Figure 4) is found, in general, to have higher 


\section{Climatological Winds $(\mathrm{m} / \mathrm{s})$}
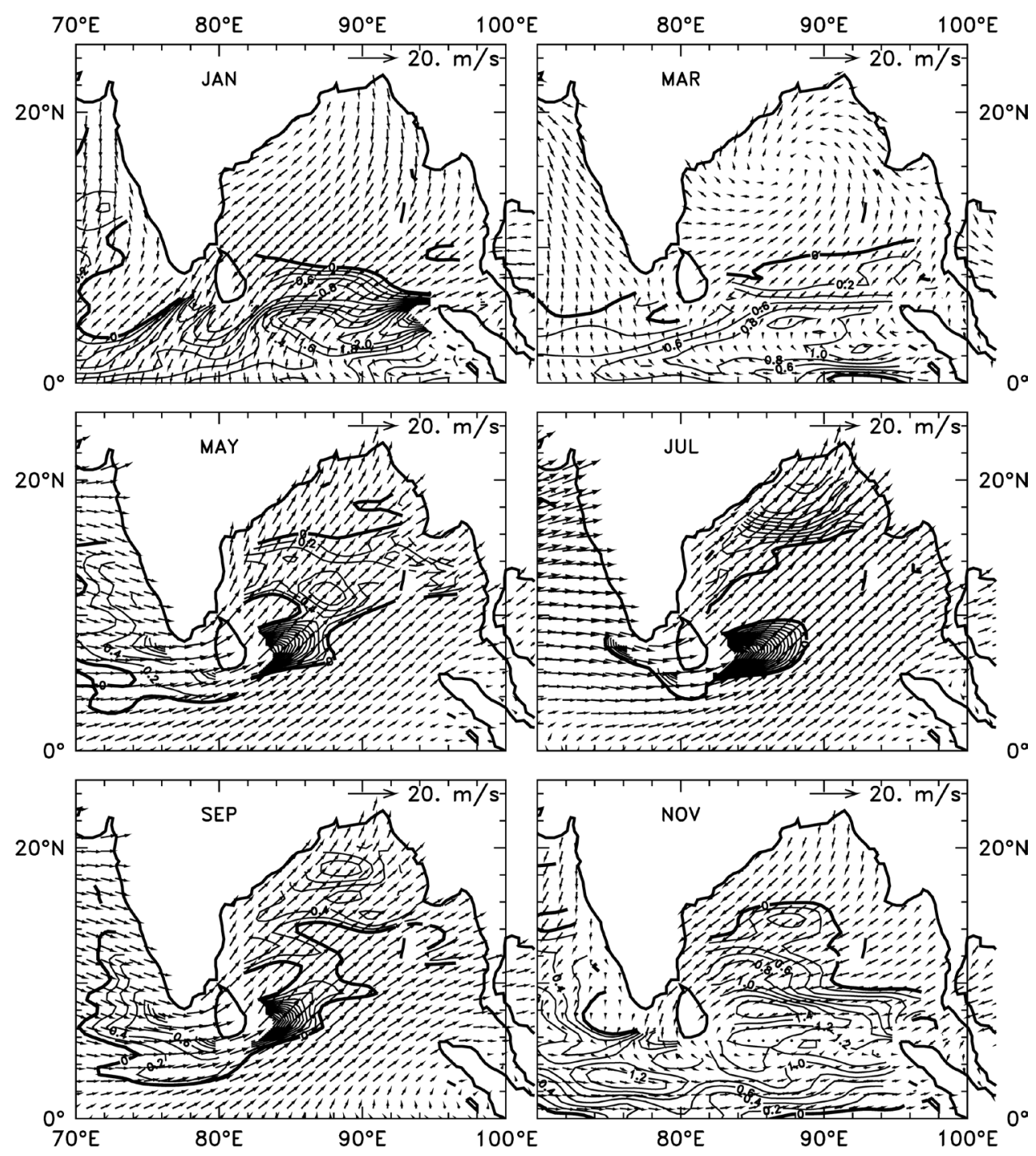

Figure 4. Bimonthly maps of winds $\left(\mathrm{m} \mathrm{s}^{-1}\right)$ over the Bay of Bengal from QuickSCAT (QSCAT). Monthly climatology is for the period $2000-2006$. Wind vectors at every $0.5^{\circ}$ interval are shown. Contours are positive wind stress curl indicating regions of upward Ekman pumping.

chl a (Plate 1). Vinayachandran et al. [2005b] conducted numerical experiments using a coupled physical-biological model in order to determine the processes that lead to open ocean bloom in the southwestern bay during the NEM. An interesting result from their study is that there is significant enrichment of the surface bloom by the subsurface chlorophyll maximum. Underlying physical process in the model are vertical fluxes driven by upwelling caused by Ekman pumping and mixed layer entrainment occurring over an al- ready shallow thermocline. The bloom first develops in the zone of subsurface chlorophyll maximum, and then it feeds into the subsurface maximum when there are intense atmospheric events such as tropical cyclones. Consistent with this, shipboard observations by Madhu et al. [2006] showed that subsurface chlorophyll maximum was located at shallower depths during the northeast and southwest monsoons compared to the spring season. The bloom seen around Sri Lanka is also partly due to Ekman pumping. This manifests 


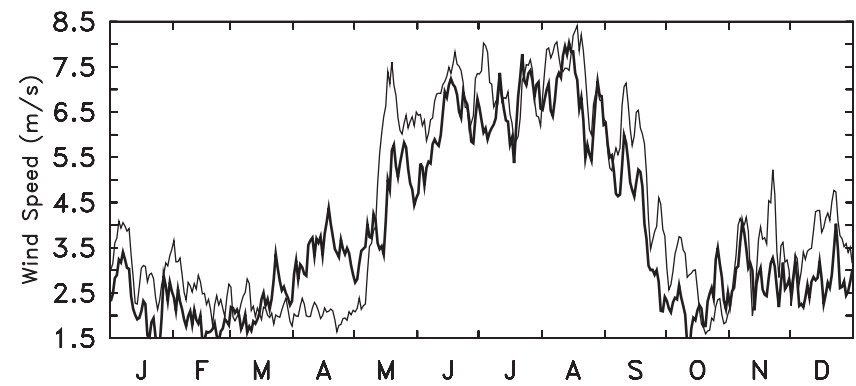

Figure 5. Wind speed averaged over the southern $\left(10^{\circ}-15^{\circ} \mathrm{N}, 80^{\circ}-\right.$ $100^{\circ} \mathrm{E}$, thin line $)$ and northern $\left(15^{\circ}-25^{\circ} \mathrm{N}, 80^{\circ}-100^{\circ} \mathrm{E}\right.$, thick line Bay of Bengal.

in two patches: one that drives the Sri Lanka dome and the other off the southeastern corner of Sri Lanka [Vinayachandran et al., 2004]. In fact, Ekman pumping also is favorable for upwelling (Figure 4) in the northwestern bay during the SWM. However, there is no evidence yet that this process causes an increase in chl $a$ in that region.

\subsection{Surface Circulation}

Early large-scale observational programs in the Indian Ocean such as the International Indian Ocean Expedition, the Global Atmospheric Research Program (GARP), the First GARP Global Experiment, and Indian Ocean Experiment did not throw much light on the seasonal circulation in the bay. The hydrography of the bay, beginning with the early observations of Sewell [1929] through observations made by National Institute of Oceanography, Goa, India, until the first half of 1990s, has been reviewed by Varkey et al. [1996]. Schott and McCreary [2001] and Shankar et al. [2002] have provided summaries of the circulation near the western boundary and the monsoon circulation in the bay, respectively. We focus on the basin-wide circulation and discuss its relevance to biological activity.

Early ideas of surface circulation in the bay were derived from ship drifts [Cutler and Swallow, 1984]. This data set enabled the delineation of the East India Coastal Current (EICC) and its seasonal cycle [Shetye et al., 1991, 1993, 1996]. Unlike in the Arabian Sea, the seasonal reversal of circulation in the bay does not follow monsoon wind reversal consequent to the combination of local and remote forcing that determines the seasonal cycle of surface circulation [Potemra et al., 1991; Yu et al., 1991; McCreary et al., 1996b; Vinayachandran et al., 1996; Eigenheer and Quadfasel, 2000].

The surface circulation in the bay is best organized during March-April (Figure 7). During this period, there is a well- defined anticyclonic gyre with a poleward EICC along the western boundary [Scherbinin et al., 1979; Legeckis, 1987; Shetye et al., 1993; Sanilkumar et al., 1997]. The poleward EICC is well developed by February and persists through May with a transport of about $10 \mathrm{~Sv}$ [Shetye et al., 1993]. The EICC then turns eastward north of $19^{\circ} \mathrm{N}$. The southward flow of this anticyclonic gyre occurs to the west of the Andaman Islands, and this flow feeds into the westward Winter Monsoon Current [Hastenrath and Greischar, 1991; Shankar et al., 2002]. The anticyclonic gyre begins to disintegrate in May and disappears completely by June.

During the SWM, intense currents are found to the south and east of Sri Lanka where the Summer Monsoon Current (SMC) curves around Sri Lanka and flows into the bay [Vinayachandran et al., 1999]. There is intense coastal upwelling along its southern coast, and the SMC transports cold upwelled water along its path [Vinayachandran et al., 2004], leading to the formation of a cold pool [Joseph et al., 2005]. The summertime EICC flows northward till about $15^{\circ} \mathrm{N}$ where it turns eastward to feed into the eastward flowing North Bay Monsoon Current (NBMC) [Vinayachandran and Kurian, 2007]. Both NBMC and the SMC feed into an eastward drift, which flows into the Andaman Sea.

In the open bay, circulation during the NEM months of November and December is characterized by a northwestward drift (Figure 7). The EICC flows southward during this period carrying low-salinity water en route [Shetye et al.,

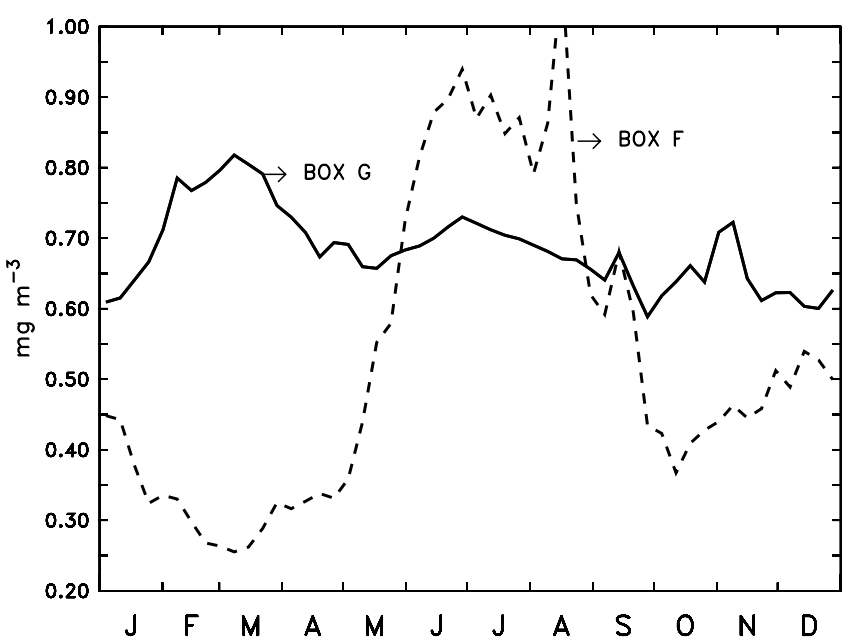

Figure 6. Annual cycle of chl $a\left(\mathrm{mg} \mathrm{m}^{-3}\right)$ along the southern part of east coast of India (dashed curve) and along the northeastern coast of Bay of Bengal (solid curve). For the former, average chl $a$ for the oceanic region within the box bounded by $79^{\circ}-81^{\circ} \mathrm{E}, 10^{\circ}-15^{\circ} \mathrm{N}$ (box F shown in Plate 1c) is presented, and for the latter it is for the box bounded by $92^{\circ}-95^{\circ} \mathrm{E}, 16^{\circ}-21^{\circ} \mathrm{N}$ (box G shown in Plate $1 \mathrm{~b}$ ). 
1996]. Circulation in the southwestern bay during this period consists of a cyclonic gyre [Vinayachandran and Yamagata, 1998]. East of Sri Lanka, the EICC bifurcates: one part continues along the coast of Sri Lanka into the Arabian Sea, and the other flows eastward into the bay [Vinayachandran et al., 2005a].

3.2.1. Advection by monsoon currents. Several instances of patches of high chl $a$ being advected by currents are visible in the bay. The best example of this feature is the advection by the Southwest Monsoon Current around India and Sri Lanka [Vinayachandran et al., 2004]. The SMC advects chl $a$-rich water from the coast of India toward Sri Lanka and from the coast of Sri Lanka into the bay. During the NEM, the EICC, which flows equatorward along the Indian coast, advects chlorophyll-rich water along its route. As the EICC bifurcates, satellite images show that high chl $a$ is located along the path of the EICC [Vinayachandran et al., 2005a].

3.2.2. Outflow of river plumes. High chl $a$ is seen off the mouths of rivers dumping into the bay. Satellite images of chl $a$ suggest that discharge from these rivers can often penetrate several hundred kilometers offshore. The direction of flow and its offshore extent are dependent on discharge volume and prevalent winds (Figure 4) and currents (Figure 7). Here we examine the features of outflow from major rivers discharging into the bay.

There is a large outflow from the mouth of the Irrawady River into the bay, which attains its peak during the SWM. During October-December, a patch of high chl $a$ flows directly outward, and then the prevailing currents advect this plume in a northwestward direction (Plate 2a). This flow (Plate 3a) weakens during January (Plate 2c), and during spring it is directed eastward, and most of the high chl $a$ is seen in the northern coastal region of the Andaman Sea (Plates 2d-2f).

Similar features are also found to be active off the mouth of Ganges-Brahmaputra River. After the withdrawal of the SWM, when the EICC in northern part of the Indian coast flows equatorward, the high-chl $a$ region clings to the coast (Plate 2h). This is consistent with the movement of suspended sediments obtained from OCM imageries [Chauhan et al., 2005]. When the currents reverse, the chl $a$ plume flows offshore directly, away from the coast into the open bay (Plate 2i). During spring, this plume can be traced several hundred kilometers to the south reaching as far south as $17^{\circ} \mathrm{N}$ (Plate $2 \mathrm{e}$ )

The river plume emanating from the mouth of the Mahanadi flows southward along the Indian coast during the $\mathrm{NEM}$, and then, at about $19^{\circ} \mathrm{N}$, it flows offshore (Plates $2 \mathrm{a}$, $2 \mathrm{~b}$, and $2 \mathrm{~g}$ ). Altimeter data suggest that this occurs around an anticyclonic eddy near the coast. The EICC meanders offshore as a result of this eddy, defining a sharp boundary for the high-chl $a$ patch. During March, when the EICC flows poleward, the river plume is pushed northward before flowing offshore (Plates 2d and 2f).

The influence of eddies is also seen on the river plume from the Godavari-Krishna river system. During October 2002, an anticyclonic eddy located off its mouth (Plate 3c) advected chl $a$-rich water in a circular pattern (Plate $2 \mathrm{~g}$ ). Farther north, offshore flow between two cyclonic eddies caused the river plume from the Mahanadi to advect away from the coast. Sometimes, the plume off the GodavariKrishna flows offshore under the influence of mesoscale ocean circulation features (Plate 2f).

\subsection{Impact of Cyclones}

Tropical cyclones are strong weather systems that form over tropical oceans with anticlockwise winds in the Northern Hemisphere. Cyclones are associated with strong winds, reaching up to $85 \mathrm{~m} \mathrm{~s}^{-1}$ [Emanuel, 2003], which induce divergent circulation in the ocean. Deepening of the mixed layer by entrainment and mixing as well as cooling of the sea surface temperature is caused by cyclones. Physical forcing by a cyclonic storm can simulate phytoplankton production in the ocean [Taylor, 1989]. Episodic winds during a cyclone churn up the water, entraining nutrients into the shallow euphotic layer and thereby enhancing $\operatorname{chl} a$ in the near-surface layer.

The bay experiences several cyclones during the OctoberDecember period. Intense atmospheric convection during a cyclone leads to dense cloud cover, thus making it difficult for the satellite sensors to provide good coverage of ocean color images. However, ocean color images by OCTS, SeaWiFS, OCM, and MODIS have been able to capture the impact of cyclones on the bay chl $a$ in several instances. A remarkable increase in chl $a$ took place in the northern bay after the 1999 supercyclone [Nayak et al., 2001; Patra et $a l ., 2007]$. The same supercyclone caused an increase in primary productivity in the southwestern bay [Madhu et al., 2002]. Passage of a cyclone over the bay during NovemberDecember, 2000 also led to a substantial increase in sea surface chl $a$ and primary productivity [Rao et al., 2006]. Cyclones lead to intense, localized, short-lived blooms in the bay during the NEM [Vinayachandran and Mathew, 2003].

Since the northern bay is highly stratified, impact of cyclones is much weaker compared to other oceanic regions such as the Arabian Sea, which are weakly stratified. For example, the cyclone during 4-7 November 1996 affected the northwestern part of the bay, which is strongly stratified because of freshwater effects. The winds reported by the 

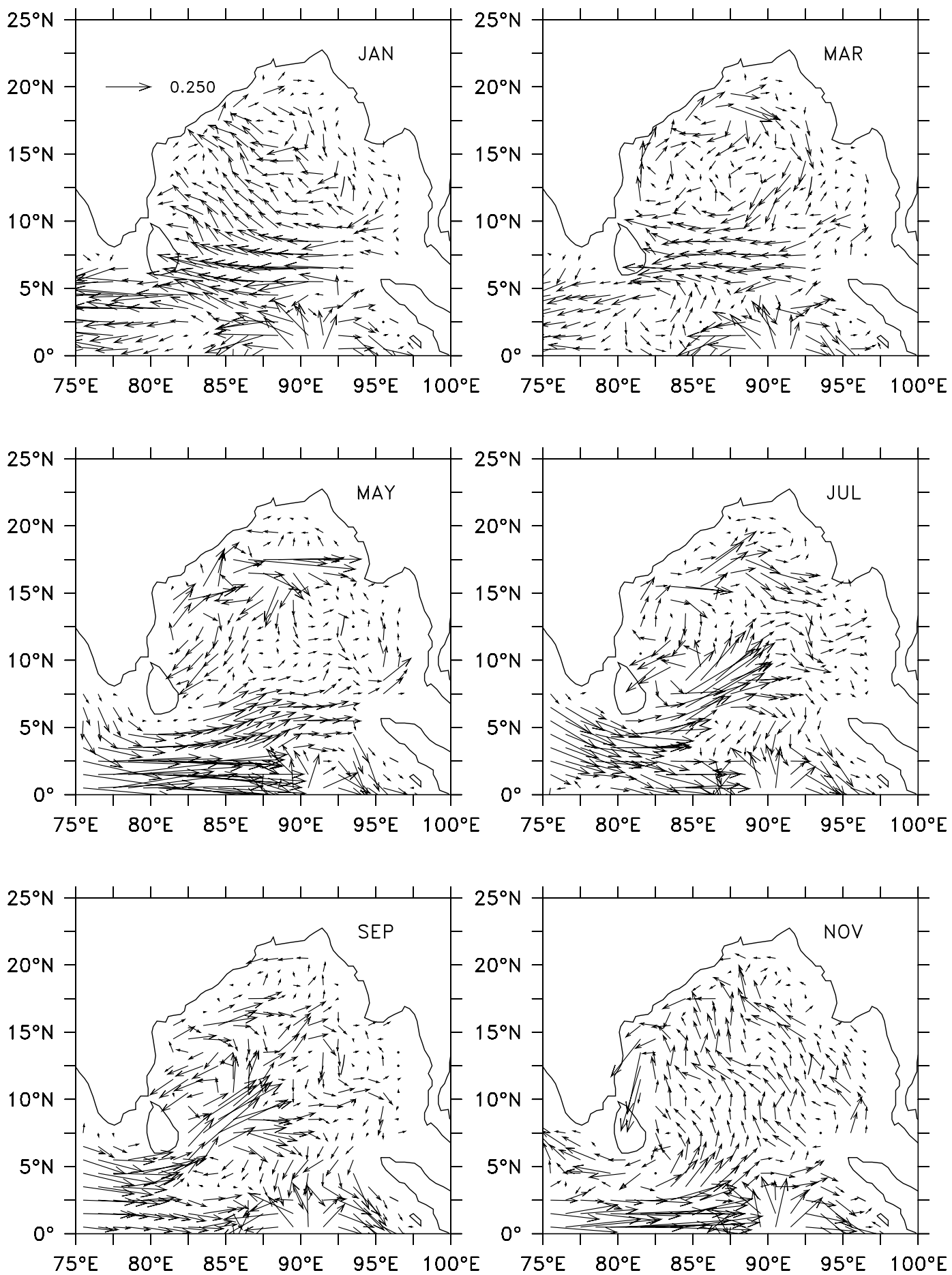

Figure 7. Surface circulation in the Bay of Bengal from Ocean Surface Current Analyses-Real time data set obtained from www.oscar.noaa.gov. The ocean surface currents $\left(\mathrm{m} \mathrm{s}^{-1}\right)$ are calculated by combining geostrophy and Ekman dynamics along with a buoyancy term using sea level anomalies from altimeters, winds from QSCAT, and sea surface temperature (SST) from advanced very high resolution radiometer data [Bonjean and Lagerloef, 2002]. 

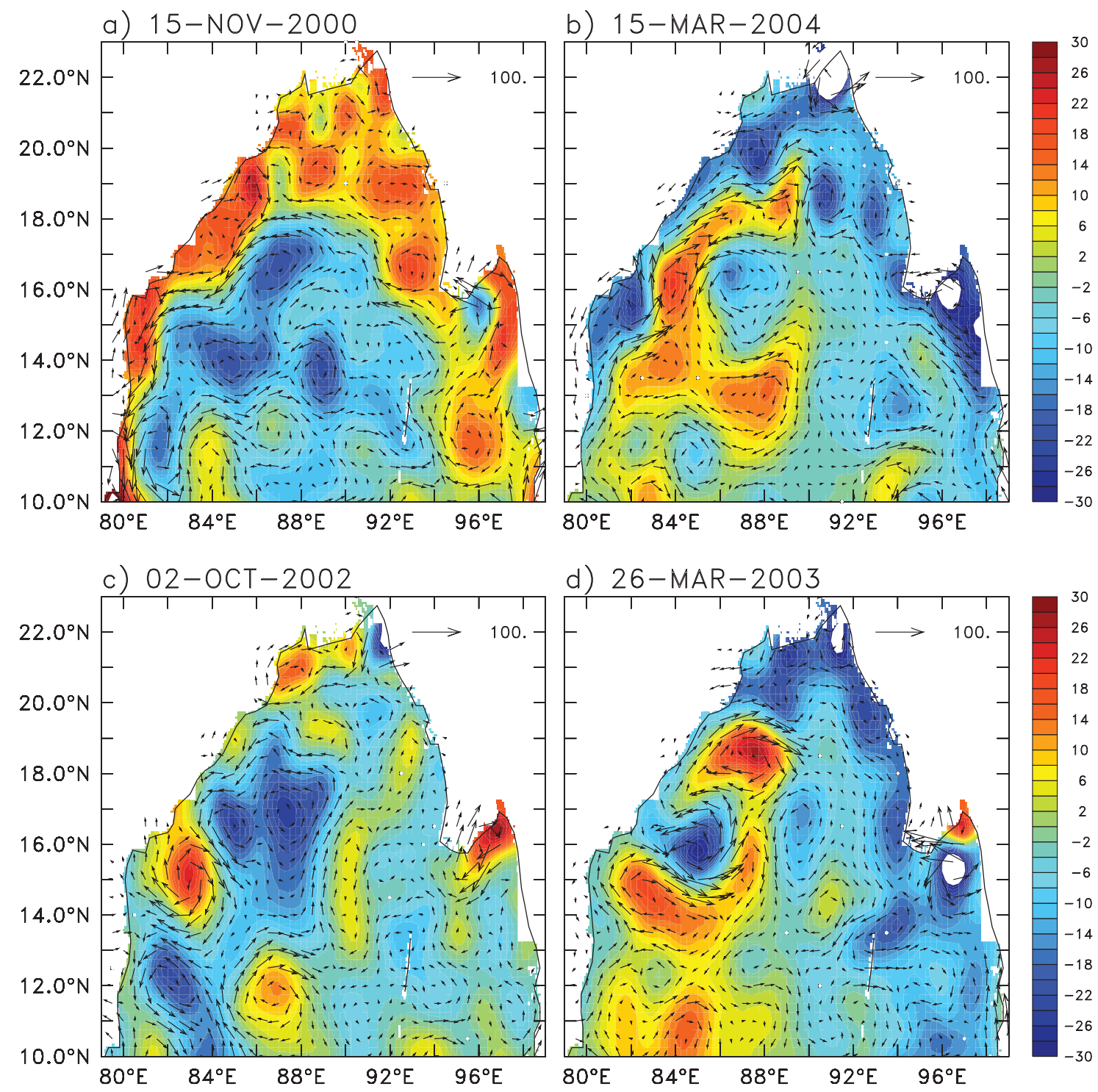

Plate 3. Sea level anomalies (color shading), from satellite altimetry, and geostrophic currents (vectors) for selected days (shown above each plot).

India Meteorological Department during this cyclone were in the range of 39-42 $\mathrm{m} \mathrm{s}^{-1}$ [Mathew, 2003]. These winds were associated with strong cyclonic curl and caused a dip in sea surface temperature (SST) of about $2^{\circ} \mathrm{C}$ as seen from advanced very high resolution radiometer data, and altimeter observations showed that the sea level dipped by about $5 \mathrm{~cm}$ along the track of the cyclone. Here chl $a$ increased from nearly oligotrophic conditions to about $2 \mathrm{mg} \mathrm{m}^{-3}$ as a result of this cyclone. The region of influence was small, and the bloom disappeared after about 2 weeks suggesting that the blooms triggered by the cyclones are short-lived as well as highly localized [Vinayachandran and Mathew, 2003; Patra et al., 2007].

In the southern bay, however, where stratification is weaker than in the north, there is significant increase in chl $a$ in response to cyclones. This has been illustrated by another cyclone during 23-28 December 2000. This cyclone formed in the southern bay east of Sri Lanka and hit Sri Lankan and Indian coasts. Maximum intensity of the cyclone to the east of Sri Lanka was seen on 24 December when the winds 


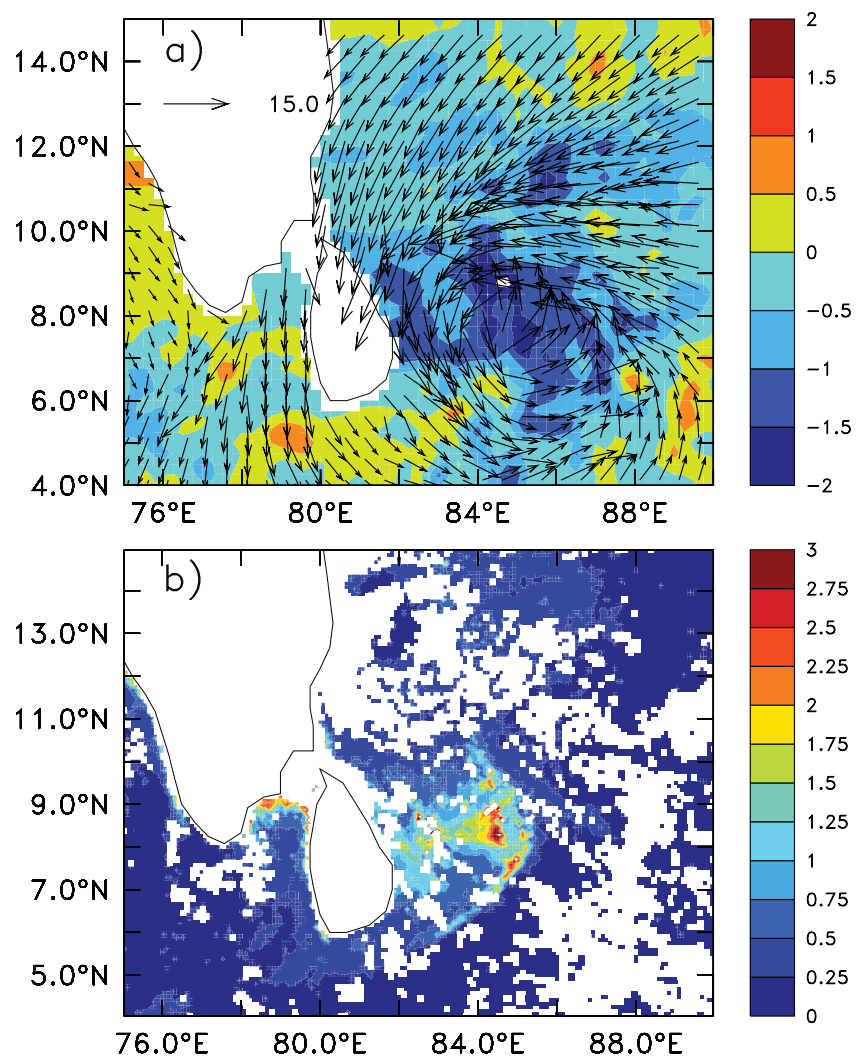

Plate 4. (a) QSCAT winds (vectors in $\mathrm{m} \mathrm{s}^{-1}$ ) for 24 December 2000 and change in SST from 21 December 2000 to 26 December 2000 from TRMM microwave imager SST data (color shading in ${ }^{\circ} \mathrm{C}$ ). (b) Chlorophyll $a$ concentration (mg $\mathrm{m}^{-3}$ ) from SeaWiFS during 26-31 December 2000.

(Plate 4a) increased to $16 \mathrm{~m} \mathrm{~s}^{-1}$ from a low $7 \mathrm{~m} \mathrm{~s}^{-1}$ on 22 December. A fully developed anticlockwise curl was also observed during 23-25 December 2003. TRMM microwave imager SST data indicate that the cyclone led to a cooling of the SST by $2^{\circ} \mathrm{C}-2.5^{\circ} \mathrm{C}$ in the vicinity of the cyclone (Plate $4 a)$. Very clear signals of the phytoplankton bloom is seen between $82^{\circ}$ and $86^{\circ} \mathrm{E}$ and $6^{\circ}$ and $10^{\circ} \mathrm{N}$ from weekly SeaWiFS images. Before the impact of cyclone, the region had low chl $a$ in the range of $0.1-0.2 \mathrm{mg} \mathrm{m}^{-3}$. There are not many data points available during the period of the cyclone because of cloud cover, but clear enhancement of chl $a$ is seen in the images after the passage of the cyclone. The chl $a$ increased to nearly $3.0 \mathrm{mg} \mathrm{m}^{-3}$. In the southwestern bay, the thermocline domes upward in response to local wind stress curl, and therefore cyclones are able to work more efficiently than in the north in bringing nutrients to the near-surface layer.

Several monsoon depressions form over the bay during the summer monsoon months of June-September. These depressions are also associated with high wind speeds and low pressure at their center. However, there is no evidence yet that they generate conditions favorable for phytoplankton blooms. The monsoon depressions form mostly in the northern bay, usually to the north of about $15^{\circ} \mathrm{N}$. This region is generally under the influence of large freshwater influx and consequently is strongly stratified [Vinayachandran et al., 2002]. As a result, it appears that the depressions are unable to inject nutrients into the mixed layer.

\subsection{Eddies}

Cyclonic eddies are associated with upward movement of the thermocline, and the associated upward velocities can upwell nutrients into the euphotic zone [Falkowski et al., 1991]. Cyclonic eddies can increase productivity of the bay by injecting nutrients into the oligotrophic waters during the SWM [Prasanna Kumar et al., 2004]. Observations during the 2003 SWM, however, did not show high chl $a$ or productivity associated with a cyclonic eddy [Muraleedharan et al., 
2007]. It is nearly impossible to test this hypothesis during the SWM using satellite data because of poor data coverage. An attempt was made to associate the cyclonic eddies seen in satellite altimetry with SeaWiFS during the cloud-free season, and this revealed several interesting features. During October-December, the southwestern bay is characterized by low sea level because of a seasonal cyclonic gyre, and the eddies could not be clearly distinguished. The cyclonic eddies were fewer in number in the eastern half (i.e., to the east of about $90^{\circ} \mathrm{E}$ ) and were also much weaker compared to those in the west (Plate 3). Therefore the analysis was limited to the January-April period. A cyclonic eddy was defined to occur when the negative sea level anomaly becomes less than $10 \mathrm{~cm}$. Several eddies were found in the altimeter data, and one example is shown in Plates 5a and $5 \mathrm{~b}$. The satellite altimetry (Plate 5a) suggests that a patch of high chl $a$ seen around $16^{\circ} \mathrm{N}, 86^{\circ} \mathrm{E}$ (Plate $5 \mathrm{~b}$ ) is associated with a cyclonic eddy.
Associating high-chl $a$ patches with eddies in the western bay has to be done cautiously. For regions that are not too far from the coast, high-chl $a$ patches can be merely due to advection from river plumes (see section 3.2.2) rather than local blooming resulting from nutrient enhancement. Such an instance is presented for 25 April 2001. There is a cyclonic eddy (Plates $5 \mathrm{c}$ and $5 \mathrm{~d}$ ) at about $85^{\circ} \mathrm{E} 18^{\circ} \mathrm{N}$. The chl $a$ in this region is about $0.25 \mathrm{mg} \mathrm{m}^{-3}$ larger than the surroundings. However, this region happens to fall within the outflow of a river plume (Plate 5c). Further analyses with the help of eddy-resolving physical-biological models and in situ measurements are required to resolve this issue.

\section{SUMMARY AND CONCLUSIONS}

The physical-biological interaction in the bay, compared to its western counterpart, the Arabian Sea, is poorly studied. Chlorophyll concentration as well as primary productivity in
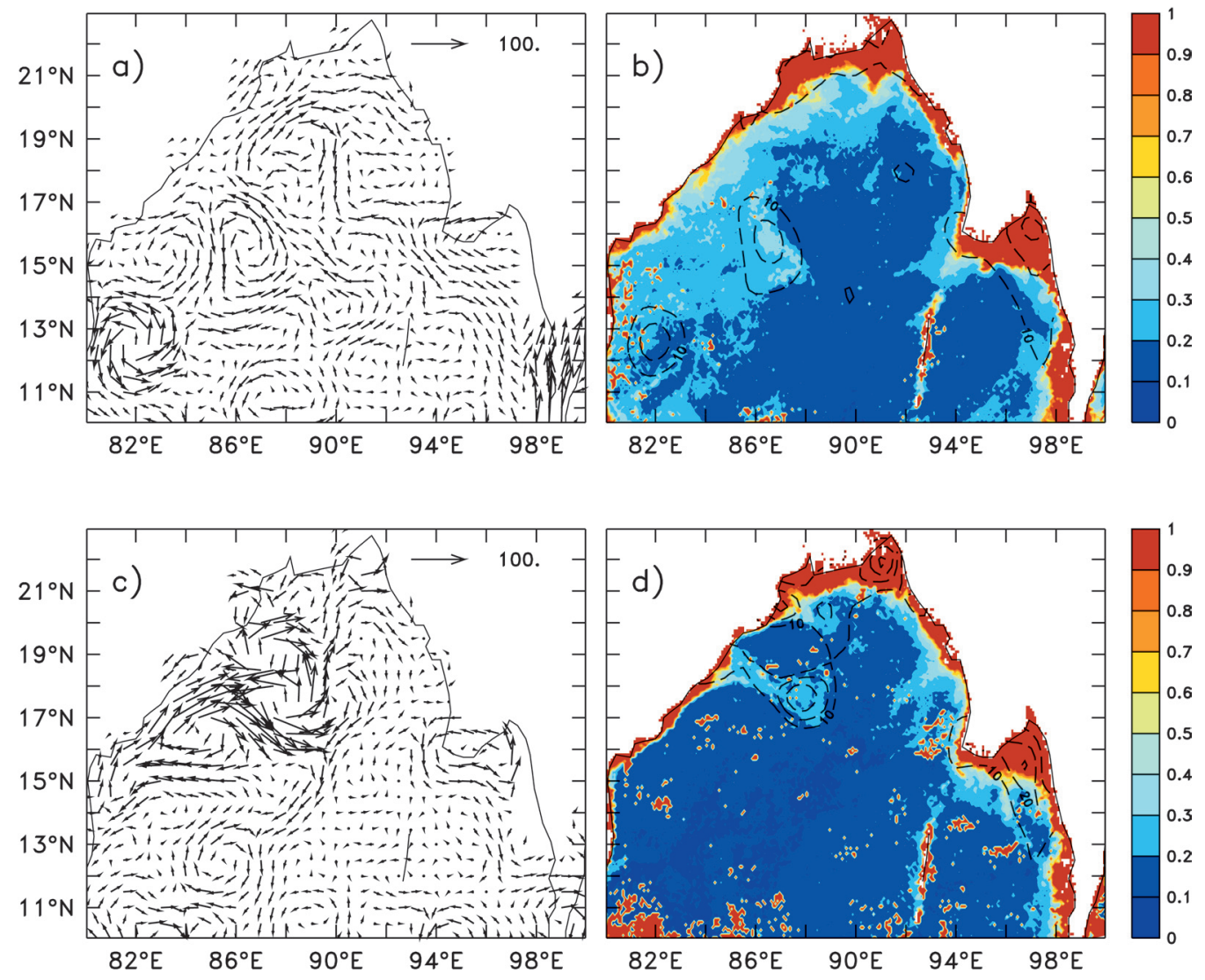

Plate 5. (a) Geostrophic currents from altimeter data for 21 January 2003. (b) SeaWiFS chl $a$ for 23 January 2003. (c) Geostrophic currents for 25 April 2001. (d) SeaWiFS chl $a$ for 23 April 2001. 
the bay is much less than that of the Arabian Sea. Nevertheless, several recent studies using either shipboard observations or satellite data suggest that physical processes control the biological activity in the bay. In this paper, we have first identified regions in the bay that have higher biological activity using about 8 years of data from SeaWiFS and then examined qualitatively the role of physical processes in enhancing biological activity.

In the open bay, cyclonic circulation associated with the doming of thermocline (and nutricline) is found to be an important process. This can happen at varying space and time scales. During the NEM, a cyclonic gyre that occupies the southwestern bay through the season is associated with high chl $a$. The Sri Lanka dome, a much smaller cyclonic gyre, is also associated with high chl $a$ driven by nutrient enrichment because of Ekman pumping. At smaller time scales, cyclonic eddies that span 100 to $200 \mathrm{~km}$ and last for 1 to 2 weeks are also found to have higher chl $a$. An interesting feature of this process is the development of subsurface chlorophyll maximum. The phytoplankton bloom develops first at subsurface levels, and the surface signature appears later. This has been illustrated in a model simulation [Vinayachandran et al., 2005b] for the case of the southwestern bay during the NEM. Prasanna Kumar et al. [2007] also found a similar feature for the case of cyclonic eddies during monsoon transition periods using observations. Tropical cyclones that lift the thermocline and entrain nutrient-rich water into the euphotic zone also cause phytoplankton blooms, and this process is more common during OctoberDecember. Coastal upwelling enhances biological activity in three regions: along the southern coast of Sri Lanka during the SWM, the southern part of Indian east coast during the SWM, and the northeastern coast of the bay during December-March. Highest values of chl $a$ are found along the coastline at the mouths of rivers. The chl $a$-rich water flows out into the open ocean or along the coast depending on coastal currents. Along the Indian coast, the most important factor that affects the offshore outbreak of river plumes is the EICC: its departure from the coast, meandering, and eddies.

There are several aspects of physical-biological interaction in the bay that future studies should address. Recent observations and satellite data have revealed many new facets. Most challenging among such problems may be the interaction between the river plume and the mesoscale feature of circulation. Processes within eddies, particularly in the presence of strong stratification, remain to be understood. It is during the SWM that river discharge has the largest impact on the coastal regions. Unfortunately, satellite data have very poor coverage during SWM because of cloud cover. Therefore, direct measurements are crucial to understand the interaction between river plumes and open ocean. Another interesting issue that can be addressed by direct measurements alone is the role of subsurface chlorophyll maximum, especially its maintenance and role in the enhancement of surface chl $a$. So far, only one modeling study addressing the impact of physical processes on bay biology has been carried out, and it focused only on the winter bloom in the southwestern bay. Further modeling studies are required to address other issues. Several recent studies have brought out different facets of the variability of the climate of the Indian Ocean region and the active role of the oceans. These events, the Indian Ocean dipole in particular, have affected the ocean biology in the equatorial Indian Ocean, in the Arabian Sea, and in the bay [Murtugudde et al., 1999; Vinayachandran and Mathew, 2003; Sarma, 2006; Vinayachandran et al., 2007]. Some of these events have been well captured by high-quality satellite data. Analyses of data sets together with model experiments are necessary to unravel the mechanisms that cause such variability.

Acknowledgments. This study was funded by the MeteorologyOceanography Programme of the Space Applications Centre, ISRO, Ahmedabad, and the INDOMOD programme of the Ministry of Earth Sciences, Government of India through INCOIS. The altimeter products were produced by SSALTO/DUACS and are distributed by AVISO with support from CNES. Thanks to IFREMER (http://www.ifremer.fr/cersat/en/data/data.htm) for QuickSCAT winds. Thanks to the SeaWiFS project and the Distributed Active Archive Center at the GSFC, Maryland, for the production and distribution, respectively, of these data. Three-day mean TMI SST, version bmaps-v04 has been obtained from SSMI (http://www. ssmi.com/tmi/tmi_browse.html). Ferret and GMT were used for graphics.

\section{REFERENCES}

Bonjean, F., and G. S. E. Lagerloef (2002), Diagnostic model and analysis of the surface currents in the tropical Pacific Ocean, $J$. Phys. Oceanogr., 32(10), 2938-2954.

Chauhan, O. S., A. S. Rajawat, Y. Pradhan, J. Suneethi, and S. R. Nayak (2005), Weekly observations on dispersal and sink pathways of the terrigenous flux of the Ganga-Brahmaputra in the Bay of Bengal during the northeast monsoon, Deep Sea Res., Part II, 52, 2018-2030.

Cutler, A. N., and J. C. Swallow (1984), Surface currents in the Indian Ocean (to $25^{\circ} \mathrm{S}, 100^{\circ} \mathrm{E}$ ): Compiled from historical data archived by the Meteorological Office, Bracknell, UK, Rep. 187, 42 pp., 36 charts, Inst. of Oceanogr. Sci., Wormley, U. K.

Eigenheer, A., and D. Quadfasel (2000), Seasonal variability of the Bay of Bengal circulation inferred from TOPEX/Poseidon altimetry, J. Geophys. Res., 105, 3243-3252.

Emanuel, K. (2003), Tropical cyclones, Science, 31, 75-104. 
Falkowski, P. G., D. Ziemann, Z. Kolber, and P. K. Bienfang (1991), Role of eddy pumping in enhancing primary production in the ocean, Nature, 352, 55-58.

Gauns, M., M. Madhupratap, N. Ramaiah, R. Jyothibabu, V. Fernandes, J. T. Paul, and S. Prasanna Kumar (2005), Comparative accounts of biological productivity characteristics and estimates of carbon fluxes in the Arabian Sea and the Bay of Bengal, Deep Sea Res., Part II, 52, 2003-2017.

Gomes, H. R., J. I. Goes, and T. Saino (2000), Influence of physical processes and freshwater discharge on the seasonality of phytoplankton regime in the Bay of Bengal- The southwest and northeast monsoon, 1992-1993, Cont. Shelf. Res., 20(3), 313-330.

Hastenrath, S., and L. Greischar (1991), The monsoonal current regimes of the tropical Indian Ocean: Observed surface flow fields and their geostrophic and wind-driven components, J. Geophys. Res., 96, 12,619-12,633.

Hood, R. R., et al. (2008), Research opportunities and challenges in the Indian Ocean, Eos Trans. AGU, 89(13), 125.

Joseph, P. V., K. P. Sooraj, C. A. Babu, and T. P. Sabin (2005), A cold pool in the Bay of Bengal and its interaction with the activebreak cycle of monsoon, CLIVAR Exchanges, 10(3), 10-12.

Jyothibabu, R., P. A. Maheswaran, N. V. Madhu, T. T. M. Asharaf, V. J. Gerson, P. Venugopal, C. Revichandran, T. Balasubramanian, T. C. Gopalakrishnan, and K. K. C. Nair (2004), Differential response of winter cooling on biological production in the northeastern Arabian Sea and northwestern Bay of Bengal, Curr. Sci., 87, 783-791.

Legeckis, R. (1987), Satellite observations of a western boundary current in the Bay of Bengal, J. Geophys. Res., 92, 12,97412,978 .

Lévy, M., D. Shankar, J.-M. André, S. S. C. Shenoi, F. Durand, and C. de Boyer Montégut (2007), Basin-wide seasonal evolution of the Indian Ocean's phytoplankton blooms, J. Geophys. Res., 112, C12014, doi:10.1029/2007JC004090.

Madhu, N. V., P. A. Maheswaran, R. Jyothibabu, C. Revichandran, T. Balasubramanian, T. C. Gopalakrishnan, and K. K. C. Nair (2002), Enhanced biological production off Chennai triggered by October 1999 super cyclone (Orissa), Curr. Sci., 82, 1472-1479.

Madhu, N. V., R. Jyothibabu, P. A. Maheswaran, V. J. Gerson, T. C. Gopalakrishnana, and K. K. C. Nair (2006), Lack of seasonality in phytoplankton standing stock (chlorophyll $a$ ) and production in the western Bay of Bengal, Cont. Shelf Res., 26(16), 1868-1883.

Madhupratap, M., M. Gauns, N. Ramaiah, S. Prasanna Kumar, P. M. Muraleedharan, S. N. de Souza, S. Sardesai, and U. Muraleedharan (2003), Biogeochemistry of Bay of Bengal: Physical, chemical, and primary productivity characteristics of the central and western Bay of Bengal during summer monsoon 2001, Deep Sea Res., Part II, 50, 881-886.

Martin, J. M., J. D. Burton, and D. Eisma (1981), River Input to Ocean Systems, U. N. Press, New York.

Mathew, S. (2003), Satellite derived chlorophyll $a$ distribution in the Bay of Bengal during northeast monsoon, M. Sc. thesis, 77 pp., Indian Inst. of Sci., Bangalore.

McCreary, J. P., Jr., P. K. Kundu, and R. L. Molinari (1993), A numerical investigation of dynamics, thermodynamics and mixed- layer processes in the Indian Ocean, Prog. Oceanogr., 31(3), 181-244.

McCreary, J. P., Jr., K. E. Kohler, R. R. Hood, and D. B. Olson (1996a), A four-component ecosystem model of biological activity in the Arabian Sea, Prog. Oceanogr., 37(3-4) 193-240.

McCreary, J. P., W. Han, D. Shankar, and S. R. Shetye (1996b), Dynamics of the East India Coastal Current: 2. Numerical solutions, J. Geophys. Res., 101, 13,993-14,010.

McCreary, J. P., K. E. Kohler, R. R. Hood, S. Smith, J. Kindle, A. S. Fischer, and R. A. Weller (2001), Influences of diurnal and intraseasonal forcing on mixed-layer and biological variability in the central Arabian Sea, J. Geophys. Res., 106, 7139-7155.

McGill, D. A. (1973), Light and nutrients in the Indian Ocean, in The Biology of the Indian Ocean, edited by B. Zeitzschel, pp. 53-102, Springer, New York.

McGillicuddy, D. J., Jr., L. A. Anderson, S. C. Doney, and M. E. Maltrud (2003), Eddy-driven sources and sinks of nutrients in the upper ocean: Results from a $0.1^{\circ}$ resolution model of the North Atlantic, Global Biogeochem. Cycles, 17(2), 1035, doi:10.1029/ 2002 GB001987.

Muraleedharan, K. R., P. Jasmine, C. T. Achuthankutty, C. Revichandran, P. K. Dineshkumar, P. Anand, and G. Rejomon (2007), Influence of basin-scale and mesoscale physical processes on biological productivity in the Bay of Bengal during the summer monsoon, Prog. Oceanogr., 72(4), 364-383.

Murtugudde, R. G., S. R. Signorini, J. R. Christian, A. J. Busalacchi, C. R. McClain, and J. Picaut (1999), Ocean color variability of the tropical Indo-Pacific basin observed by SeaWiFS during 1997-1998, J. Geophys. Res., 104, 18,351-18,366.

Nayak, S., R. K. Sarangi, and A. S. Rajawat (2001), Application of IRS P4 OCM data to study the impact of cyclone on coastal environment of Orissa, Curr. Sci., 80, 1208-1213.

Pant, A. (1992), Primary productivity in coastal and off-shore waters of India during two southwest monsoons, 1987 and 1989, in Oceanography of the Indian Ocean, edited by B. N. Desai, pp. 81-90, India Book House, New Delhi.

Patra, P. K., M. D. Kumar, N. Mahowald, and V. V. S. S. Sarma (2007), Atmospheric deposition and surface stratification as controls of contrasting chlorophyll abundance in the North Indian Ocean, J. Geophys. Res., 112, C05029, doi:10.1029/ 2006JC003885.

Potemra, J. T., M. E. Luther, and J. J. O'Brien (1991), The seasonal circulation of the upper ocean in the Bay of Bengal, J. Geophys. Res., 96, 12,667-12,683.

Prasanna Kumar, S., P. M. Muraleedharan, T. G. Prasad, M. Gauns, N. Ramaiah, S. N. de Souza, S. Sardesai, and M. Madhupratap (2002), Why is the Bay of Bengal less productive during summer monsoon compared to the Arabian Sea?, Geophys. Res. Lett., 29(24), 2235, doi:10.1029/2002GL016013.

Prasanna Kumar, S., M. Nuncio, J. Narvekar, A. Kumar, S. Sardesai, S. N. de Souza, M. Gauns, N. Ramaiah, and M. Madhupratap (2004), Are eddies nature's trigger to enhance biological productivity in the Bay of Bengal?, Geophys. Res. Lett., 31, L07309, doi:10.1029/2003GL019274.

Prasanna Kumar, S., M. Nuncio, N. Ramaiah, S. Sardesai, J. Narvekar, V. Fernandes, and J. T. Paul (2007), Eddy-mediated 
biological productivity in the Bay of Bengal during fall and spring intermonsoons, Deep Sea Res., Part I, 54, 1619-1640.

Qasim, S. Z. (1977), Biological productivity of the Indian Ocean, Indian J. Mar. Sci., 6, 122-137.

Radhakrishna, K., P. M. A. Bhattathiri, and V. P. Devassy (1978), Primary productivity of Bay of Bengal during August-September 1976, Indian J. Mar. Sci., 7, 94-98.

Rao, K. H., A. Smitha, and M. M. Ali (2006), A study on cyclone induced productivity in south-western Bay of Bengal during November-December 2000 using MODIS (SST and chlorophylla) and altimeter sea surface height observations, Indian J. Mar. Sci., 35, 153-160.

Rao, S. A., V. V. Gopalakrishna, S. R. Shetye, and T. Yamagata (2002), Why were cool SST anomalies absent in the Bay of Bengal during the 1997 Indian Ocean dipole event?, Geophys. Res. Lett. 29(11), 1559, doi:10.1029/2001GL014645.

Sanilkumar, K. V., T. V. Kuruvilla, D. Jogendranath, and R. R. Rao (1997), Observations of the Western Boundary Current of the Bay of Bengal from a hydrographic survey during March 1993, Deep Sea Res., Part I, 44, 135-145.

Sarma, V. V. S. S. (2006), The influence of Indian Ocean dipole (IOD) on biogeochemistry of carbon in the Arabian Sea during 1997-1998, J. Earth Syst. Sci., 115, 433-450.

Scherbinin, A. D., V. S. Arse'yev, and Y. A. Golddin (1979), The western boundary current of the Bay of Bengal, Dokl. Acad. Sci. USSR, Earth Sci. Sect., English Transl., 244, 167-168.

Schott, F. A., and J. P. McCreary (2001), The monsoon circulation of the Indian Ocean, Prog. Oceanogr., 51(1), 1-123.

Sewell, R. B. S. (1929), Temperature and salinity of the surface waters of the Bay of Bengal and Andaman Sea with reference to the Laccadive Sea, Mem. Asiat. Soc. Bengal, 9, 207-356.

Shankar, D., J. P. McCreary, W. Han, and S. R. Shetye, (1996), Dynamics of the East India Coastal Current: 1. Analytic solutions forced by interior Ekman pumping and local alongshore winds, J. Geophys. Res., 101, 13,975-13,992.

Shankar, D., P. N. Vinayachandran, and A. S. Unnikrishnan (2002), The monsoon currents in the north Indian Ocean, Prog. Oceanogr., 52(1), 63-120.

Shenoi, S. S. C., D. Shankar, and S. R. Shetye (2002), Differences in heat budgets of the near-surface Arabian Sea and Bay of Bengal: Implications for the summer monsoon, J. Geophys. Res., 107(C6), 3052, doi:10.1029/2000JC000679.

Shetye, S. R., S. S. C. Shenoi, A. D. Gouveia, G. S. Michael, D. Sundar, and G. Nampoothiri (1991), Wind-driven coastal upwelling along the western boundary of the Bay of Bengal during the southwest monsoon, Cont. Shelf Res., 11(11), 13971408 .

Shetye, S. R., A. D. Gouveia, S. S. C. Shenoi, D. Sundar, G. S. Michael, and G. Nampoothiri (1993), The Western Boundary Current of the seasonal subtropical gyre in Bay of Bengal, $J$. Geophys. Res., 98, 945-954.

Shetye, S. R., A. D. Gouveia, D. Shankar, S. S. C. Shenoi, P. N Vinayachandran, D. Sundar, G. S. Michael, and G. Nampoothiri (1996), Hydrography and circulation in the western Bay of Bengal during the northeast monsoon, J. Geophys. Res., 101, 14,011-14,025.
Taylor, G. T. (1989), Variability in the vertical flux of microorganisms and biogenic material in the epipelagic zone of a North Pacific central gyre station, Deep Sea Res., Part I, 36, 1287-1308.

Varkey, M. J., V. S. N. Murty, and A. Suryanarayana (1996), Physical oceanography of the Bay of Bengal and the Andaman Sea, Oceanogr. Mar. Biol., 34, 1-70.

Vinayachandran, P. N., and J. Kurian (2007), Hydrographic observations and model simulation of the Bay of Bengal freshwater plume, Deep Sea Res., Part I, 54, 471-486, doi:10.1016/ j.dsr.2007.01.007.

Vinayachandran, P. N., and S. Mathew (2003), Phytoplankton bloom in the Bay of Bengal during the northeast monsoon and its intensification by cyclones, Geophys. Res. Lett., 30(11), 1572, doi:10.1029/2002GL016717.

Vinayachandran, P. N., and T. Yamagata (1998), Monsoon response of the sea around Sri Lanka: Generation of thermal domes and anticyclonic vortices, J. Phys. Oceanogr., 28(10), 1946-1960.

Vinayachandran, P. N., S. R. Shetye, D. Sengupta, and S. Gadgil (1996), Forcing mechanisms of the Bay of Bengal circulation, Curr. Sci., 71, 753-763.

Vinayachandran, P. N., Y. Masumoto, T. Mikawa, and T. Yamagata (1999), Intrusion of the Southwest Monsoon Current into the Bay of Bengal, J. Geophys. Res., 104, 11,077-11,085.

Vinayachandran, P. N., V. S. N. Murty, and V. Ramesh Babu (2002), Observations of barrier layer formation in the Bay of Bengal during summer monsoon, J. Geophys. Res., 107(C12), 8018, doi:10.1029/2001JC000831.

Vinayachandran, P. N., P. Chauhan, M. Mohan, and S. Nayak (2004), Biological response of the sea around Sri Lanka to summer monsoon, Geophys. Res. Lett., 31, L01302, doi:10.1029/ 2003 GL018533.

Vinayachandran, P. N., T. Kagimoto, Y. Masumoto, P. Chauhan, S. R. Nayak, and T. Yamagata (2005a), Bifurcation of the East India Coastal Current east of Sri Lanka, Geophys. Res. Lett., 32, L15606, doi:10.1029/2005GL022864.

Vinayachandran, P. N., J. P. McCreary Jr., R. R. Hood, and K. E. Kohler (2005b), A numerical investigation of the phytoplankton bloom in the Bay of Bengal during northeast monsoon, J. Geophys. Res., 110, C12001, doi:10.1029/2005JC002966.

Vinayachandran, P. N., J. Kurian, and C. P. Neema (2007), Indian Ocean response to anomalous conditions in 2006, Geophys. Res. Lett., 34, L15602, doi:10.1029/2007GL030194.

Yu, L., J. J. O'Brien, and J. Yang (1991), On the remote forcing of the circulation in the Bay of Bengal, J. Geophys. Res., 96, 20,449-20,454.

P. N. Vinayachandran, Centre for Atmospheric and Oceanic Sciences, Indian Institute of Science, Bangalore 560 012, India. (vinay@caos.iisc.ernet.in) 